\title{
Islamic Guidance and Counseling in Developing Skills Youth Communication in The Digital Era
}

\author{
Romdiyah, Mufida Istati \\ Islamic Guidance and Counseling Department, Tarbiyah and Teacher Training Faculty \\ UIN Antasari \\ Banjarmasin Indonesia \\ mufidach@yahoo.co.id
}

\begin{abstract}
Islamic counseling and guidance is a technique which can be used to help an adolescent in developing their communication skills. Guidance and counseling services were carried out for three meetings with specific themes, including communication characteristics in the digital era, communication ethics on social media according to Islamic teaching, and training for implementing the Islamic communication ethics on social media.
\end{abstract}

Keywords-Islamic counseling, adolescent's communication in the digital era

\section{INTRODUCTION}

The digital age was born with the emergence of digital, internet networks, especially computer information technology. The new media of the digital era has characteristics that can be manipulated, network or internet. The mass media turned to new media or the internet because there was a cultural shift in the delivery of information. This digital era's media capabilities make it easier for people to receive information faster. Today's increasingly sophisticated digital technology is causing major changes in the world. Humans have been facilitated in passing access to information in many ways and can enjoy the facilities of digital technology freely.

According to reference [1] in the development of digital technology, of course, many impacts are felt in this digital era, both positive and negative impacts. The positive effects of the digital age include: (a) Information needed can be faster and easier to access. (b) The growth of innovation in various fields oriented to digital technology that facilitates processes in our work. ( c) The emergence of digital-based mass media, especially electronic media as a source of knowledge and information of the community. (d) Increasing the quality of human resources through the development and utilization of information and communication technology. (e) The emergence of various learning resources such as online libraries, online learning media, online discussions that can improve the quality of education. (f) The emergence of ebusiness such as an online store that provides various needs and makes it easy to get [1].

Positive impacts received by the public but also negatively pack dam appears to threaten the development of the future generation. Millennial generation nowadays prominently inspires innovation not only in the development of technology and knowledge but also in the social arena. In this fastchanging era, the world can't resist the trend of digital application and its impact impacts on various realms. The millennial generation, somehow, is a major impact on the development of technology-based digital applications. For example, easily facilitated crime, online games may impair mental younger generation, pornography, and copyright infringement easy to do. In the field of socio-culture, the digital era also has positive influences and negative impacts that make it a challenge to improve it. The moral decline in the community, especially adolescents and students, is one of the serious socio-cultural challenges - the pattern of interaction between people changes with the presence of digital era technology such as computers, especially in the community of middle and upper economic groups. Computers connected by telephone have opened opportunities for anyone to connect with the outside world without having to socialize directly.

In this digital era, teenagers interact more socially using social media. Social activities through Facebook, Instagram, WhatsApp, and line accounts require literacy skills that are good for teenagers. Research results from

Ref [2] stated that the influence of poor literacy on the psychological of children and adolescents. The negative impact on the psychology of negative comments on social media on children and adolescents is the tendency of children and adolescents to be accustomed to insulting others, giving rise to envy towards others, resulting in depression, being carried away by the negative comments and accustomed to talking with language is not polite [2] .

Ref [3] suggests various risk factors for the digital world need immediately addressed, considering children and adolescents are the next generations who will shortly whether or not the life of the community in the future. Equip children with the ability to independently assess and sort out the various influences of the online world; it is a fundamental step that needs to be sought. Growing online resilience in children is an important need to be done in strengthening their ability to manage various risks so that they can continue to develop into individuals tough [3].

According to reference [4], teenagers (12-22 years old) are the most vulnerable to negative influences. This problem is very difficult to overcome if it just relies on the secular West psychological theories. Islamic education is expected to 
provide a solution to these problems through functional strategy, integral and progressive. Religious teachings not only memorized but should also be presented in the spirit of assisting young people in solving the problem. This strategy could be guiding problem-solving in society and society as well as an integral understanding of his relationship with God. Teens should have the spirit that can translate itself into a superior person [4].

\section{LITERATURE REVIEW}

\section{A. Relevant characteristics of digital information}

Education is changing. Digital technologies are everywhere, and they are impacting what, where, how and why students learn, and from whom they learn. Digital information is different from its physical counterpart in many ways. It can be rapidly duplicated, easily distributed and able to be stored in multiple locations. These factors mean that it can be hard to control and eliminate. Having an appreciation of these unique characteristics is the key to developing an effective prevention and incident response plan. However, the effect is the most felt when a school needs to respond to an incident involving misuse of digital technology. School staff feels that they have not been involved in achieving a successful outcome.

The reality is, however, having greater control does not necessarily equate to a better outcome. Schools are advised to recognize and understand the nature of digital technology and have brought and developed systems and processes to manage these.

The 'viral' nature of digital communication enables information to spread rapidly and reaches a wide audience. It can make it very difficult to know who has received the information or how it will spread further. It also requires any action to minimize the harm that can be caused by this communication to be taken quickly.

Once digital information or items are created, it can delete all copies. For example, digital information can be: (1 ) stored on a range of digital devices such as smartphones, laptops and internet servers as it is communicated - for example, an email or chat message. (2) copied and communicated automatically or to a schedule making it difficult to know what information is stored where. For example, a smartphone automatically synchronizes stored information with a laptop computer or to the 'Cloud.' (3) retrieved or restored from the archive or after deletion using easily accessible tools. (4) temporarily stored on a device. For example, a device will download information to display a website and then can delete it when the web browser is closed [5].

\section{B. Characteristic of Adolescence in Digital Era}

The age of adolescents is 12-15 years (early adolescence), 15-18 years (middle adolescence), and 18-21 years (late adolescence). The characteristics of adolescents regarding physical changes, cognitive development, and psychosocial development will affect an adolescent's adaptability in facing the challenges of life in the digital age.
Obtained research findings that there were significant differences in characteristics between generation $\mathrm{Z}$ and other generations, one of the main distinguishing factors was the mastery of information and technology. For generation $\mathrm{Z}$ information and technology are things that have become a part of their lives, because they are born where access to information, especially the internet has become a global culture so that it affects their values, views, and goals in life. The rise of generation $\mathrm{Z}$ will also create new challenges for management practices in organizations, especially for the practice of human resource management [6].

\section{Electronic Media in the Service of Adolescent Communication}

Better understand how adolescents use electronic media for communication, we start by describing the many diverse ways in the which such communication can take place. Among youth today, popular communication forms include naked e-mail, instant messaging, text messaging, chat rooms, bulletin boards, blogs, networking utilities such as MySpace and Facebook, video sharing such as YouTube, photo sharing such as Flickr, massively multiplayer online computer games such as World of Warcraft, and virtual worlds such as Second Life and Teen Second Life [7].

\section{Islamic Guidance and Counseling}

Adolescents in cultures around the world have historically benefited from the presence of "informal" counselors and mentors, both within the school system as well as within the community/society as a whole. These are typically teachers, administrative staff, parent volunteers, older peers within the school system and, in some cases, religious/spiritual leaders in the community/society. However, as time went on, sociopolitical and economic conditions changed. Migration and urbanization presented new challenges among youth who lost traditional familial-social networks. These are required communities to define vocational learning and systematicness pathways in the form of "guidance" for their youth. Over time, the need for professional, unbiased, confidential and private counseling strategies was recognized by many schools around the world [8].

The term "school counseling" broadly refers to the needs of students in several areas of development, such as academic, career, and personal. Experts agree that professional school counseling programs should be comprehensive in scope, preventative in design and developmental in nature. " The term "guidance" refers to a specific trajectory within the field of counseling, a pathway to helping students choose a vocational or career path. " Guidance is the process of helping people make important choices that affect their lives, such as choosing a preferred lifestyle. One distinction between guidance and counseling focuses on helping individuals choose what they value most, counseling focuses on helping them make changes [9].

Islamic guidance and counseling aim to make individuals happy Muslims in the world and the hereafter by becoming a healthy person. The characteristics of a healthy person include recognizing himself as a creature of God, accepting the 
existence of himself and the environment positively, making decisions and living according to the guidance of Islamic values, and actualizing themselves as human beings who adhere to Islamic religious values. A distinctive feature of Islamic guidance and counseling is the implementation of services based on the values of the Qur'an and Hadith.

Based on the results of research Daris Tamin found that: Quranic Contemplation in four general phases of Counseling, namely: Exploration, Reading Scripture, Developing, and Supplication. In particular, each session consists of seven steps, namely: (1) build engagement counselee to open his / her heart to accept the Quran as a "heart medicine", the instructions for peace of mind and happiness in life; (2) exposing the problems of the counselee; (3) identify the norms of adopted counselee; (4) guiding counseling for contemplations with Quran in the order: recited, guiding understand the meaning of the verse, raised the focus on the problem, the main message conveying the message, reflecting the message of verses in everyday life; and expand the discussion; (5) made a commitment to change the behavior of current and future; (6) invited to join in the spiritual community; and (7) guided prayer [10].

\section{E. Communication in Islamic Perspective}

The concept of communication ethics according to the Qur'an is the reciprocal relationship that causes unilateral or both parties to depend on wisely or what is called akhlaqulkarimah. The communication ethics is based on the characteristics of honesty in communication, both impartial and impartial, fairness and propriety, accuracy of information, freedom of responsibility, conduct of constructive criticism, then the principles of gentle apostles, glorifying words, being gentle (wise), words that are good (pleasant), words that are honest, trustworthy and not lie and effective, using the method of the approach of al-hikmah al-mau'izah al-hasanah [11]

When people receive news from various media, they tend to be fast spread again. Without checking the truth in a story This, in contrast to the attitude that must be done by Muslims as written in Surah Al-Hujarat: 49 (6), which means " you who have believed, if there comes to you a disobedient one with information, investigate, lest you harm a person out of ignorance and become, over what you have done, regretful".

The results of the study of the authors of the study of the principles of communication in Islam as written by Muslimah [12], [13]. As explained below about the principles of communication-based on the Qur'an and the hadith of Islamic communication ethics there are six principles of the style of speech or conversation (qaulan), namely:

- Qaulan is sadidan (true, straight, honest words). The word " qaulan sadidan" is called twice in the Qur'an. First God told human a conveying qaulan sadidan (right speech) in the affairs of orphans and descendants, namely (QS. An-Nisa: 4 (9) which means "you (executors and guardians) fear [injustice] as if they [themselves] left weak offspring behind and feared for them. So let them fear God and speak a word of appropriate justice. Second, God commanded qaulan sadidan after taqwa, as in the name of Allah in QS. AlAhzab (33): 70 whose translation is " you who have believed, fear Allah and speak words of appropriate justice." So, Allah SWT says to people always be cautious, accompanied by the right words. Later God will reverse your deeds, forgive your sins, whoever obeys Allah and His Messenger will surely achieve great luck. So, true words are the principle of communication contained in the Qur'an and contain several meanings of true understanding.

- Qaulan Balighan (words that imprint on the soul, right on target, communicative, easy to understand). This statement is found in QS An-Nisa (4): 63 which means " Those are the ones from whom God knows what is in their hearts, so it turns away from them but admonish them and speak to them a far-reaching word". The word "baligh" in Arabic means up, about the target or achieving the goal. If it is associated with qaul (speech or communication), "baligh" means fluent, clear meaning, light, right to use what is desired. Therefore the principle of qoulan balighan can be translated as the principle of effective communication. In order for communication to be right on target, the style of speech and the message delivered should be adjusted to the level of intellectuality of the communicant and use the language understood by them.

- Qaulan Masyura (mild words). God's Word is explained in QS. Al-Israa': 17 (28) which means: " And if you [must] turn away from the needy mercy from your Lord which you expect, then speak to them a gentle word." Maisura, as seen in the verse above, is actually rooted in the word yasara, which etymologically means easy or appropriate. Qaulan maisura is actually more appropriate to mean "pleasant speech," his opponent is a difficult statement. If the qaulan ma'rufa contains good words of instruction, the qaulan maisura contains encouraging things via easy and appropriate words. Communication with qaulan maisura which means that the message delivered is simple, easy to understand and can be understood spontaneously without having to think twice.

- Qaulan Layyina (meek words). The command uses gentle words is contained in the Qur'an (QS Thaahaa (20): 44. This means that "And speak to him with gentle speech that perhaps he may be Reminded or fear [Allah]." From the verse, it can be concluded that Qaulan Layina means soft talk, with a sound that is pleasant to hear, and full of hospitality, so that it can touch the heart, meaning not to amplify the sound, such as yelling, raising the voice. Anyone doesn't like talking to rude people. The Prophet always spoke softly, so that every word he spoke touched the heart of anyone who heard it. Layina is satirical words, not with straightforward or straightforward words, especially rough.

- Qaulan Karima (noble words). Islam teaches to use noble words in communicating with anyone. This noble word is as in the verse of the Qur'an (QS Al-Isra (17): 23) which means " And you have decreed that you did not worship except Him, and to parents, good treatment. 
Whether or not of them reach the old age [while] with you, I am not to them [so much as], "off," and do not repel them but speak to them a noble word. With the explanation above, it can be concluded that the Quranic Quran is a noble word, accompanied by respect and glory, pleasant to hear, gentle, and manners. In the context of journalism and broadcasting, Qaulan Karima means using polite words, not rude, not vulgar, and avoiding "bad taste," such as disgust, disgust, horror, and sadism. Someone's rank or rank do not judge good communication but by someone's words. Quite a lot of people who fail to communicate well with others are caused by using words that are wrong and potentially degrading others. Word problems cannot be taken lightly in communication. Because false words have implications for the quality of communication and in turn affect the quality of social relations. Even because of the wrong words of social relations it broke up completely.

- Qaulan Ma'rufa (good words). Qaulan Ma'rufa also means useful talks and raises good ( maslahat ). As Muslims who believe, our words must be kept from vain words, whatever we say must always contain advice, soothe those who hear it. Do not let us only look for the ugliness of others, who can only criticize or find fault with others, slander and incite.

Allah mentions the word Qaulan Ma'rufa in the verses of the Qur'an (Surah Al-Ahzab (33): 32) which means " O wives of the Prophet, you are not like anyone among women. If you fear Allah, then do not be soft in speech [to men], lest he in Whose heart is disease should Covet, but speak with Appropriate speech ". to realize good communication, one must always be careful, think about and reflect on what to be spoken. Emphasis on this aspect is because often the words that come out of someone's mouth result in catastrophe and catastrophe for the person who says it and even for others.

\section{F. Islamic principles and regulation of communication and social interaction}

As Islam is a complete way of life, catering for all the fields of human existence and guidance for all walks of life, social, material, moral, economic and political, legal and cultural national and international, it has laid down certain factors, rules and regulations to guide all types of interpersonal communication and relationships

The growth level of new media technologies has become a global phenomenon. In recent years, worldwide internet usage has been led to the popularity of social network sites. Facebook is ok, Twitter and YouTube are the common websites that have shaped cooperative structures where human interactions are encouraged proactively.

Islam, through the Qur'an, hadith, and Sunnah, has provided principles and methods of interpersonal communication, human interaction and relationship between Muslims and non-Muslims, in order to enjoy peace, equality, brotherhood, and prosperity and pleasure from God in the hereafter. Allah says, "Those who believe that real brothers. Therefore, make peace (mend willing times) between the two brothers and fear of God, that ye may Obtain mercy." (AlHujurat (49): 10). In line with this, the Messenger of Allah said: "The likeness of believers in compassion, love and social call is like a body that is one individual has the disease, the whole body feels the suffering of participation and literacy" (al-Hadith).

Such interactions among Muslims are based on goodwill, sympathy, and compassion, while the interaction between the Muslims with other peoples is the relationship introductions, mutual help, and justice. In this regard, Allah says: "O mankind, we have created you a nation and people who are nation and tribes that you may know each other-knowing. Verily, you are the most favorite among you. "(Al-Hujurat (49): 13). Further, Allah says about the attitude to be taken by Muslims against people of other Faiths as follows:" Allah does not forbid you to be kind and fair Applicable to Reviews those who fight you not for religion and not (also) drive you of the country. Truly, Allah loves those who apply fair. "(AlMumtahanah 8). In Islam, Muslims understand that interaction between people is not limited to matters of interest but rather than keeping the universal human dignity and status as a single entity and put the rules that will go up the essence of humanity. Relationships between individuals, namely as the followings: ( 1 ) Mutual respect for ct and honorariums (2) Spread the love saying (3) Justice, fairness and balance. (4) Equation and equality behavior. (5) Sticking to virtue. (6) Freedom. (7) Tolerant and tolerance. (8) Helping each other. ( 9 ) Keeping promises [14].

\section{DISCUSSION}

Implementation of guidance and counseling services are conducted through three themes of the material provided includes stage 1 communication characteristics in the digital age, stage 2 Ethics communication through social media in accordance with the value of the teachings of Islam, and stage 3 Training applies the concept of communication ethics in Islam in the media social. In stage 1, the counselor provides understanding to adolescents about the characteristics of the digital era, namely the delivery of information digitally. The feature of digital information that must be understood consists of Digital information is different from its physical counterpart in many ways. (1) rapidly duplicated and easily distributed, e.g., a message posted via social media is reposted elsewhere by friends or email sent to a list of recipients within a very short time frame. (2) stored in multiple locations, e.g, photos can be stored simultaneously on a laptop, a smartphone and in the Cloud. (3) created and co- communicated automatically, the eg smartphone can synchronize emails with another device or online service. (4) stored with varying levels of 'discoverability', eg image files that can only be accessed using a password or other method of authentication.

Stage 2 Ethics of communication through social media that are in accordance with the values of the teachings of Islam. (1) Qaulan sadidan (true, straight, honest words). The word " qaulan sadidan" is called twice in the Qur'an. First, God told a man to deliver sadidan qaulul (right words) in the affairs of orphans and descendants, namely (Surat an-Nisa (4 ) Verse 9) which means "you (executors and guardians) fear [injustice] as if they [themselves] left weak offspring behind and feared for 
them. So let them fear God and speak the words of appropriate justice. Saying correct the communication principles contained in the Qur'an and contains some of the meaning of true understanding. (2) Balighan Qaulan (words that imprint on the soul, right on target, communicative, easy to understand). This statement is found in QS An-Nisa (4): 63 which means " Those are the ones from whom God knows what is in their hearts, so it turns away from them but admonish them and speak to them a far-reaching word ". The principle of qoulan balighan can be translated as the principle of effective communication. In order for communication to be right on target, the style of speech and the message delivered should be adjusted to the level of intellectuality of the communicant and use the language understood by them. (3) Qaulan Masyura (mild words). God's Word is explained in QS. Al-Israa '(17): 28 which means: " And if you [must] turn away from the needy mercy from your Lord which you expect, then speak to them a gentle word". Communication with qaulan maisura which means that the message delivered is simple, easy to understand and can be understood spontaneously without having to think twice. (4) Qaulan Layyina (meek words). The command to use these meek words is found in the Qur'an (QS Thaahaa (20): 44. It means " And speak to him with gentle speech that may be reminded or fear [Allah]". Qaulan Layina means weak talk soft, with a pleasant voice, and full of hospitality, so that it can touch the hearts of the intention was not raised her voice, like a snapped, raising his voice. (5) Qaulan Karima ( noble words). Islam teaches to use noble words in communicating with anyone. This noble word is as in the verse of the Qur'an ( Surah Al-Isra (17): 23) which means " And you have decreed that you did not worship except Him, and to parents, good treatment. Whether or not they reach the old age [while] with you, I am not to them [so much as], "off," and do not repel them but speak to them a noble word." Q my darling is a noble word, accompanied by respect and glory, pleasant to hear, gentle, and manners.

(6) Qaulan Ma'rufa (good words). Qaulan Ma'rufa also means useful talks and raises good (maslahat). As Muslims who believe, our words must be kept from vain words, whatever we say must always contain advice, soothe those who hear it. Do not let us only look for the ugliness of others, who can only criticize or find fault with others, slander and incite (counselees) to practice using the most commonly used social media such as using Instagram and Line. Counselees implementation of 6 ethical principles of communication in the delivery of the message to his friend can be a photo, video, and text using the social media. Counselors give counselees the opportunity to send messages and respond to messages received. The counselor responded to the response from his friend after delivering it. Then carry out reflection and evaluation of what has been done by the counselee. Training and habituation continued until the counselee realized the importance of applying the ethical principles of communication in Islam in the current digital eraAcknowledgment.

\section{CONCLUSION}

The application of guidance and counseling services carried out through 3 themes of material provided includes stage 1 Characteristics of communication in the digital era, (1) rapidly duplicated and easily distributed, (2) stored in multiple locations, (3) created and communicated automatically (4 ) stored with varying levels of 'discoverability'

Stage 2 Ethics of communication through social media that are in accordance with the values of the teachings of Islam.

- Qaulan sadidan (right speech, straight, honest ". The correct of sayying the communication principles contained in the Qur'an and contains some of the meaning of true understanding.

- Qaulan Balighan (speech which made an impression on the soul, right target, communicative, easy to understand) The principle of qoulan balighan can be translated as the principle of effective communication adjusted to the level of intellectuality of the communicant and using the language understood by them.

- Qaulan Masyura (mild words) Communication with qaulan maisura which means that the message delivered is simple, easy to understand and can be understood spontaneously without having to think twice.

- Qaulan Layyina (meek words). Qaulan Layina means gentle conversation, the sound catchy, and full of hospitality,

- Qaulan Karima (noble words). Qaulan karimah is noble words, coupled with respect and glorify, pleasant, gentle, and a good attitude.

- Qaulan Ma'rufa (good words). Qaulan Ma'rufa also meaningful talks that are useful and cause good ( maslahat ).

Stage 3 Training applies the concept of ethical communication in Islam on social media. Counselors train teens (counselees) to practice using the most used social media. Counselors give counselees the opportunity to send messages and respond to messages received. Then carry out reflection and evaluation of what has been done by the counselee.

\section{REFERENCES}

[1] W. Setiawan, "Digital era and the challenge," 2017. [Online]. Available: http://eprints.ummi.ac.id/151/2/1. [Accessed: 05-Nov-2018].

[2] N. Pratiwi and N. Pritanova, "Effect of digital literacy on psychological children and adolescents," Journal of SEMANTIK Scientific journal Indonesian Language and Literature Education Study Program STKIP Siliwangi Bandung, vol. 6, no. 1, pp. 11-24, 2017.

[3] W. Hendriani, "Growing online resilience in children in the age of digital technology," Scientific Gathering Proceedings of Indonesian Development Psychology Association Role of Developmental Psychology in the Growth of Humanity in the Digital Age, pp. 52-58.

[4] M. Sofa, "Anticipating moral degradation in the nadwa global era," Journal of Islamic Education, vol. 7, no. 2, pp.321-335, 2013.

[5] Ministry of Education Tetahu O Te Matauranga, A Guide For Schools Safe And Responsible For Schools A Companion To The Guidelines For Surrender And Retention Of Property And Searches, Newzeland Government, 2015.

[6] B. Bencsik, and R. Machova, "Knowledge sharing problems from the viewpoint of intergeneration management," In ICMLG2016 - 4th 
International Conference on Management, Leadership, and Governance: ICMLG2016. Academic Conferences and publishing limited, p. 42, 2016.

[7] K. Subrahmanyam, and P. Greenfield, "Online communication and adolescent relationships," The Future of Children, vol. 18, no. 1, pp. 119-146, 2008.

[8] N. C. Gysbers, and P. Henderson, "Comprehensive guidance and counseling programs: a rich history and a bright future," Professional School Counseling, vol.4, no.4, pp. 246, 2001.

[9] C. Raghavan, Gender english in counseling and guidance in postprimary education - advocacy brief, Bangkok: UNESCO, 2009

[10] D. Tamin, "Applying Qur'anic contemplation in counseling," The International Journal of Counseling and Education, vol.1, no.1, pp. 1-8, 2016 .
[11] Pledge, "The ethical conception of communication according to the Qur'an (a thematic interpretation study)," Thesis. Islamic Theology Concentration of Interpretation of Hadith. Postgraduate Program of Alauddin State Islamic University (UIN) Makassar, 2012.

[12] M. Women, "Communication ethics in Islamic perspectives," Journal of Socio-Cultur, vol. 13, no. 2, pp. 115-125, 2016.

[13] R. Wazir, "Communication in islam principles based on the Qur'an and al-sunnah," HADIS: The Authorized Scientific Journal, no. 10, pp. 47$56,2015$.

[14] D. A. I. A. E.-F. Khalil, "The Islamic perspective of interpersonal communication," Journal of Islamic Studies and Culture, vol. 4, no. 2, 2016. 